\title{
STUDY OF THERMAL INTERACTION OF CELL-PHONE RADIATIONS WITHIN HUMAN HEAD TISSUES
}

\author{
BASANDRAI ${ }^{1,2}$, DHAMI AK ${ }^{2}$ \\ ${ }^{1}$ Department of Physics, I.K Gujral Punjab Technical University, Jalandhar, Punjab, India. ${ }^{2}$ Department of Physics, Lovely Professional \\ University, Phagwara, Punjab, India. Email: basandraideepak@yahoo.com
}

Received: 16 July 2016, Revised and Accepted: 22 July 2016

\section{ABSTRACT}

Objective: The present investigation included in the study of penetration depth, attenuation coefficient, and specific absorption rate (SAR) with varying distance between the source of radiation and exposed human head tissues (skin, fat, brain, and bone). In addition, corresponding temperature increases inside these various human head tissues are also calculated.

Methods: A theoretical model based on Maxwell equations, microscopic form of ohm's law and Joule's law of heating effect has been proposed for this study.

Results: By assuming the distance of $1 \mathrm{~cm}$ and exposure time of 5 minutes, the highest SAR was estimated to be $1681.7 \mathrm{~W} / \mathrm{kg}$ for the brain tissue at $900 \mathrm{MHz}$ and $4038.5 \mathrm{~W} / \mathrm{kg}$ for $1800 \mathrm{MHz}$. Maximum skin depth and attenuation coefficient were found to be in the case of fat and brain tissue, respectively, among rest head tissues. The corresponding highest temperature rise for the brain tissue was calculated to be $2.31 \mathrm{~K}$ at $900 \mathrm{MHz}$ and $5.54 \mathrm{~K}$ at $1800 \mathrm{MHz}$ frequencies.

Conclusion: Results of this study concludes that the temperature rise in human tissue depends on SAR and the duration for which human body is actually exposed to Global System for Mobile Communication radiations.

Keywords: Electromagnetic radiation, Human head tissues, Skin depth, Attenuation coefficient, Specific absorption rate and thermal effects.

(C) 2016 The Authors. Published by Innovare Academic Sciences Pvt Ltd. This is an open access article under the CC BY license (http://creativecommons. org/licenses/by/4. 0/) DOI: http://dx.doi.org/10.22159/ajpcr.2016.v9i6.14133

\section{INTRODUCTION}

The tremendous increases in the number of communication devices including cell phones and base stations have increased the public concern about the safety of these devices. Although there are reports on biological effects of cell phone radiations, at the same time, studies indicate otherwise too. Hence, there has been no conclusive evidence, till recently, on the ill effects of cell-phone radiations. But recently, Researchers at the National Toxicology Program, a federal interagency group under the National Institutes of Health has shown that cell phone radiation can cause cancers in the brain and heart [1]. Similarly, few years back, the bio-initiative report which was released in December 2012 gave conclusive and substantial evidence of the risks associated with cell-phone radiations. This report reviewed over 1800 new scientific studies and included 29 independent science and medical experts from around the world [2]. Such studies have further increased the public concern about the hazardous effects of cell-phone radiation.

The electromagnetic waves of different power levels and different frequencies from these mobile phones and base stations penetrate deep inside the human body and hence initiate adverse health effects [3-5] Different radiation depending on their frequency and conductivity has different penetration power, which can be measured by a parameter called Skin depth. Usually, conductor transmits electrical signal or energy in the form of alternating current, which further produced magnetic field. With the change in intensity of electric current, magnetic field intensity also changes. According to Maxwell equation changing magnetic field further produced an electric field which opposes current density. This decrease in the value of current density is called skin effect. The depth at which current density falls to 1 /e of its initial value is called skin depth. The reciprocal of skin depth is called attenuation coefficient. Skin depth also helps to measure the rate of absorption of radiation per unit mass by human tissue also called specific absorption rate (SAR).
Exposure to these radiations increases the local temperature of exposed tissue instead of increasing the total body temperature, which causes several kinds of thermal effects. Although no harmful exposure has been found when the mobile phone is in switched off mode [6], in operating mode, head has been found to be the most susceptible victim of these radiations, as the phone is kept close to it while talking [7]. In the reported studies, there are variations in the allowable rise in temperature for safe exposure. It has been reported that a maximum increase of temperature by $3.5^{\circ} \mathrm{C}$ in the brain does not lead to any direct physiological damage, but changes in thermoregulatory behavior have been noticed with 0.2 $0.3 \mathrm{~K}$ temperature increase in hypothalamus. In another study, safe limit for temperature increase is suggested to be $4.5 \mathrm{~K}$ in the brain to avoid any physiological damage for the maximum exposure time of 30 minutes $[8,9]$. Hence considering above factors, the maximum rise in brain temperature rise within the safe limit has been taken to be $4.5 \mathrm{~K}$

The studies in literature are based on various kinds of interaction mechanism of radio frequency radiations with human biological tissue. This further depends on the tissue dielectric properties, frequency of the source and corresponding temperature elevation of the concerned tissue. The reported studies to calculate the increase in temperature have not taken into consideration the permittivity parameter which contributes to the radiation absorption through SAR. Hence, the present work has been done to establish a relation between temperature rise and SAR by taking into consideration the permittivity parameter. In addition, the behavior of SAR by varying distance and exposure time has been studied for frequencies at 900 and $1800 \mathrm{MHz}$.

\section{METHODS}

Determination of SAR (using equation 1) includes induced electric fields inside a human body at different penetration depth and dielectric properties of biological tissue $[10,11]$. 
$\operatorname{SAR}=\left(\sigma+\omega \varepsilon_{o} \varepsilon_{r}\right) E^{2} / \rho$

Where, $\sigma=$ conductivity of biological tissue, $\omega=$ angular frequency, $\epsilon_{0}=$ permittivity of biological tissue, $\epsilon_{\mathrm{r}}=$ relative permittivity of biological tissue, $E=$ induced electric field, and $\rho=$ density of biological tissue. The electrical and thermal properties of human head biological tissue at $900 \mathrm{MHz}$ and $1800 \mathrm{MHz}$ are mentioned in Table 1.

A radiofrequency source is placed at a distance " $r$ " from human head as shown in Fig. 1.

The electric field $E$ in air at a distance $r$ from cell phone radiating electromagnetic energy at power $P$ is given by Polk [12]

$\frac{P}{4 \pi r^{2}}=\frac{1}{2} \varepsilon_{0} E^{2} C$

$\mathrm{E}=\left[\frac{P}{2 \pi \varepsilon c r^{2}}\right]^{\frac{1}{2}}$

$\mathrm{E}=7.746 \frac{\sqrt{P}}{r}$

Taking " $\mathrm{r}$ " as $1 \mathrm{~cm}, 2 \mathrm{~cm}$ and $5 \mathrm{~cm}$ and power as $1 \mathrm{~W}$, the value of induced electric field is found to be $774.6 \mathrm{~V} / \mathrm{m}, 387.3 \mathrm{~V} / \mathrm{m}$, and $154.92 \mathrm{~V} / \mathrm{m}$. SAR has been calculated by substituting these results into equation 1 .

To calculate skin depth [13] and attenuation coefficient following equation has been used

Skin depth $\delta=\sqrt{\frac{2}{\mu \sigma \omega}}$

Attenuation coefficient $\left(\alpha^{-1}\right)=1 / \delta$

$\operatorname{SAR}=\frac{3 \sigma \delta^{2}}{2 \rho}$

To calculate the relation between SAR and temperature increase, following equations have been used.

$\mathrm{J}=\sigma \mathrm{E}$

Where $\mathrm{j}$ is current density $\left(\mathrm{A} / \mathrm{m}^{2}\right), \sigma$ is conductivity $(\mathrm{S} / \mathrm{m})$ and $\mathrm{E}$ is electric field $(\mathrm{V} / \mathrm{m})$

$\mathrm{dQ}=\mathrm{I}^{2} \mathrm{r} \mathrm{dt}$

dQ is amount of heat generated, i.e., thermal energy when current I due to magnetic field is passing through a resistance $\mathrm{r}$ for time $\mathrm{dT}$.

$\mathrm{dQ}=\frac{\rho V C d T}{\sigma+\omega \varepsilon_{0} \varepsilon_{r}}$

Using equations 2-5, the relation between SAR and thermal distribution in tissue for a period of $\mathrm{dt}$ is given by:

$\mathrm{SAR}=\mathrm{C} \cdot \frac{d T}{d t}$

\section{RESULTS}

The skin depth was found to be the highest in the case of fat tissue $40.7 \mathrm{~mm}$ and $42.5 \mathrm{~mm}$ and minimum in the case of brain tissue $18 \mathrm{~mm}$ and $9.1 \mathrm{~mm}$, respectively, for 900 and $1800 \mathrm{MHz}$ frequencies (Fig. 2).

On the other hand attenuation, coefficient was found to be the highest in the case of brain tissue and minimum in the case of fat tissue (Fig. 3).

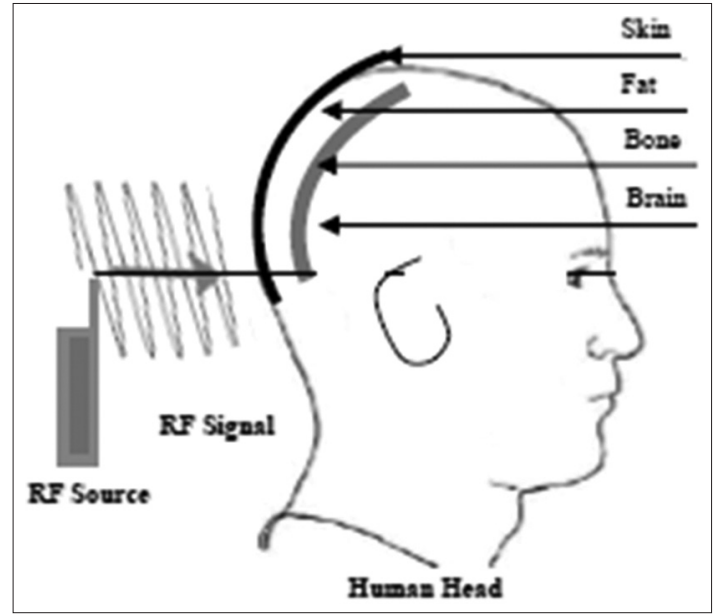

Fig. 1: Anatomy of head and position of radio frequency source

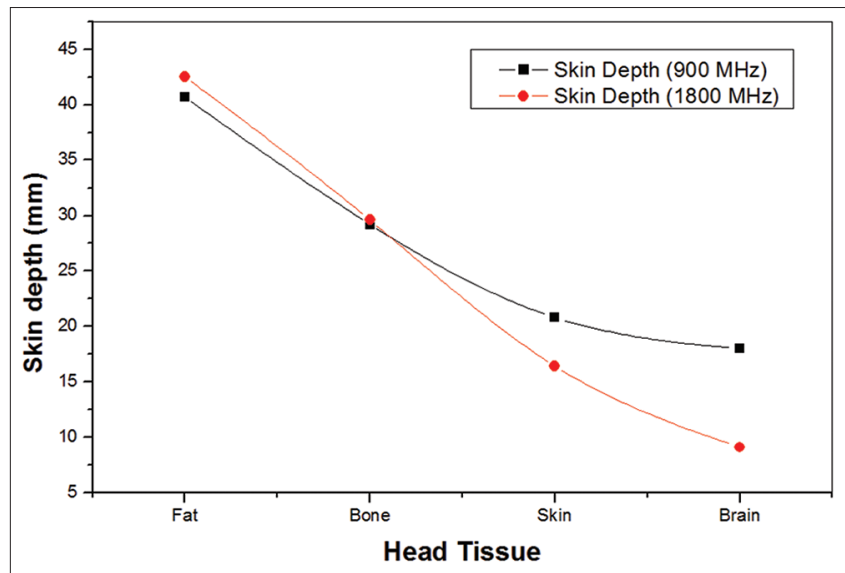

Fig. 2: Variation in penetration depth with human head tissue

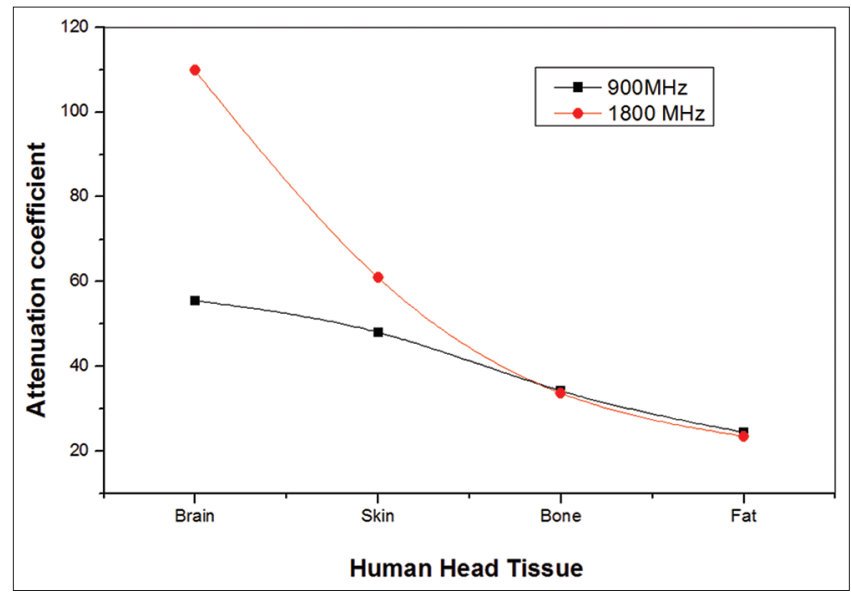

Fig. 3: Variation in attenuation coefficient with human head tissue

The SAR value was found to be highest for the brain tissue while the lowest has been observed in the head fat. SAR for the brain was found to be $1681.7 \mathrm{~W} / \mathrm{kg}$ and $4083.496 \mathrm{~W} / \mathrm{kg}$ at $900 \mathrm{MHz}$ and $1800 \mathrm{MHz}$, respectively, when the phone is held at $1 \mathrm{~cm}$ and the same for the fat is $436.96 \mathrm{~W} / \mathrm{kg}$ and $116.08 \mathrm{~W} / \mathrm{kg}$ (Figs. 4 and 5).

When the distance from the phone increased from $1 \mathrm{~cm}$ to $5 \mathrm{~cm}$, SAR value was estimated to be decreased by $96 \%$. The calculated SAR values have been used to estimate the increase in temperature of various head 
tissues with the help of equation 6 and specific heat value of concerned tissue mentioned in Table 1. Results have been plotted in Figs. 6-9.

\section{DISCUSSIONS}

Results obtained from these graphs indicates that radiation penetrates inside human head via skin tissue and easily penetrate to brain tissue via fat tissue. Maximum attenuation coefficient was found in the case of brain tissue while minimum in the case of fat tissue which indicates radiations easily penetrate from fat to brain tissue without any loss of energy. Maximum loss of energy in the form of heat energy occurred inside brain tissue. Hence, maximum temperature rise occurred in the case of brain tissue in comparison with rest head tissues. When radio frequency source is at $1 \mathrm{~cm}$ and exposure time is of 1 minute then the temperature elevation in brain, skin, bone, and fat tissue is 1.109 $\mathrm{K}, 0.611 \mathrm{~K}, 0.200 \mathrm{~K}, 0.168 \mathrm{~K}$, respectively, for $1800 \mathrm{MHz}$ frequency.

Table 1: Human head tissue dielectric properties [7]

\begin{tabular}{lllll}
\hline Tissue & Skin & Fat & Bone & Brain \\
\hline Specific heat $(\mathrm{J} / \mathrm{K} \mathrm{kg})$ & 3662 & 2378 & 1590 & 3640 \\
Mass density $\left(\mathrm{kg} / \mathrm{m}^{3}\right)$ & 1010 & 920 & 1810 & 1040 \\
Permittivity $\epsilon_{\mathrm{r}}(900 \mathrm{MHz})$ & 40.7 & 10 & 20.9 & 41.1 \\
Permittivity $\epsilon_{\mathrm{r}}(1800 \mathrm{MHz})$ & 32.5 & 5.35 & 8.0 & 53.0 \\
Conductivity $\sigma(\mathrm{s} / \mathrm{m})(900 \mathrm{MHz})$ & 0.65 & 0.17 & 0.33 & 0.86 \\
Conductivity $\sigma(\mathrm{s} / \mathrm{m})(1800 \mathrm{MHz})$ & 0.52 & 0.078 & 0.16 & 1.7 \\
\hline
\end{tabular}

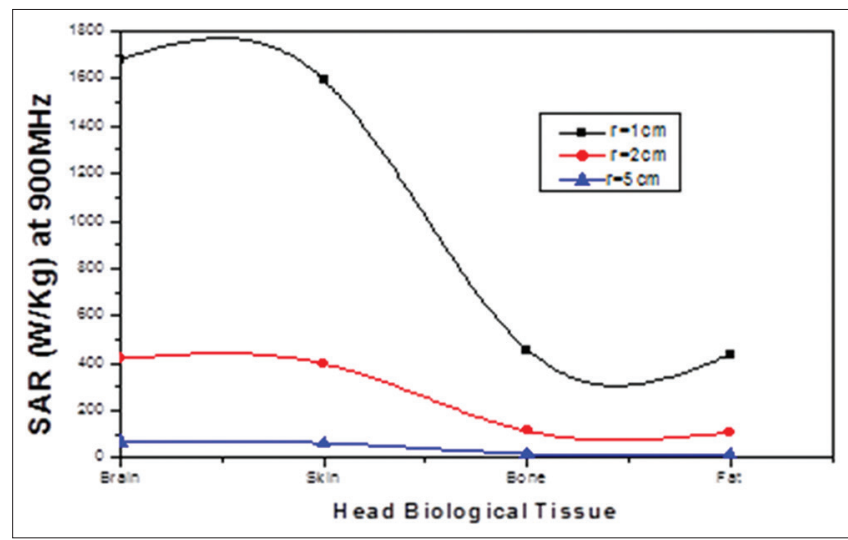

Fig. 4: Comparison of specific absorption rate level for biological tissues of head at a distance of $1 \mathrm{~cm}, 2 \mathrm{~cm}$ and $5 \mathrm{~cm}$ from cell phone for $900 \mathrm{MHz}$ frequency

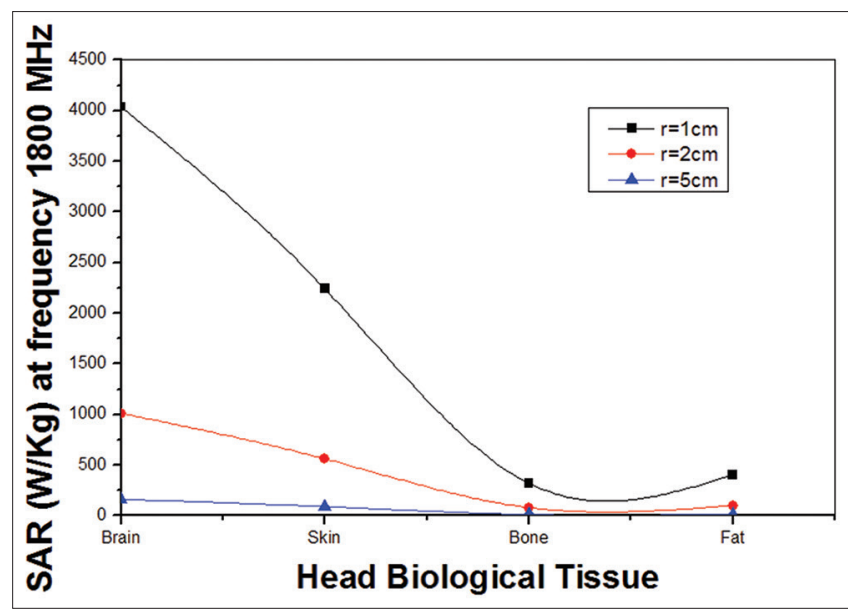

Fig. 5: Comparison of specific absorption rate level for biological tissues of head at a distance of $1 \mathrm{~cm}, 2 \mathrm{~cm}$ and $5 \mathrm{~cm}$ from cell phone for $1800 \mathrm{MHz}$ frequency
When exposure duration was increased to 5 minutes, the temperature elevation for these tissues increased to $5.547 \mathrm{~K}, 3.0579 \mathrm{~K}, 1.000 \mathrm{~K}$, $0.8405 \mathrm{~K}$ at the same frequency. Hence with the increase in exposure time from 1 minute to 5 minutes keeping radiofrequency source at a same distance of $1 \mathrm{~cm}$, the temperature increase in concerned tissue was found to be $80 \%$. Hence considering $4.5 \mathrm{~K}$ to be the safe limit for

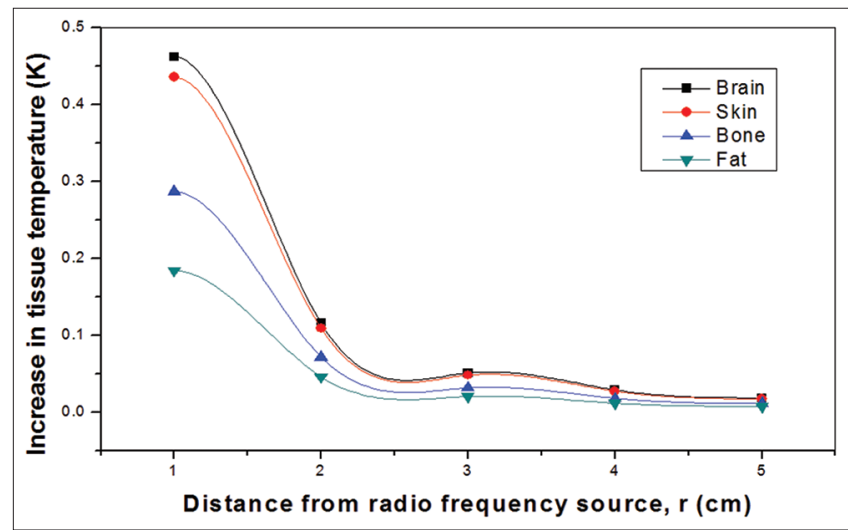

Fig. 6: The calculated temperature distribution with distance between cell-phone and head tissues (brain, skin, bone and fat) exposed to $900 \mathrm{MHz}$ frequency for 1 minute

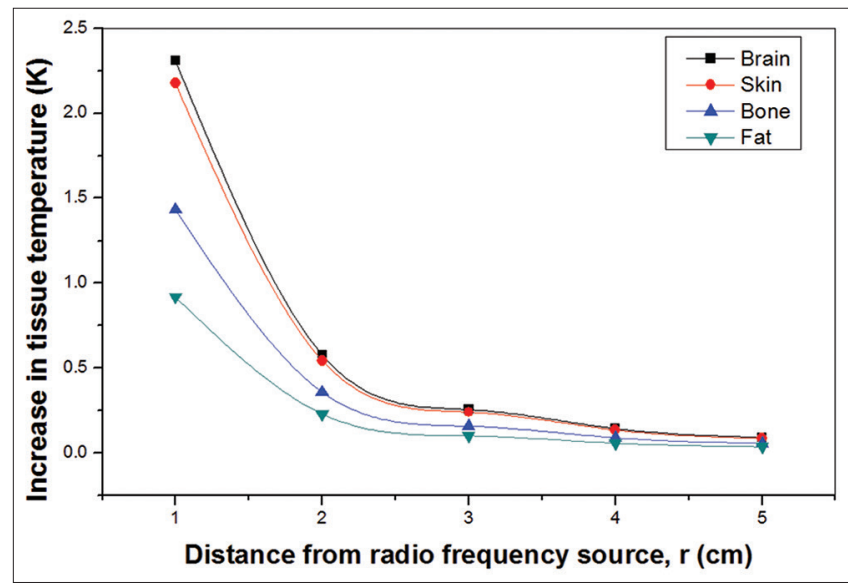

Fig. 7: The calculated temperature distribution with distance between cell-phone and head tissues (brain, skin, bone and fat) exposed to $900 \mathrm{MHz}$ frequency for 5 minutes

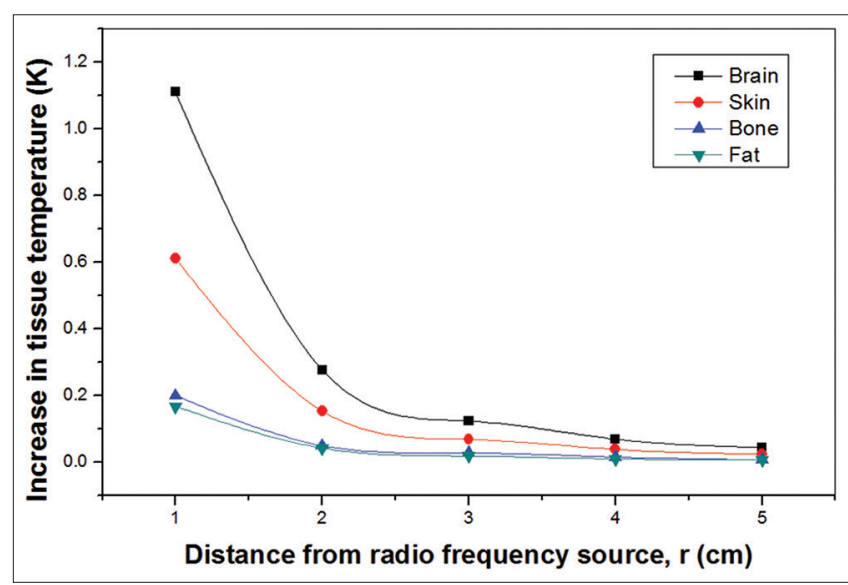

Fig. 8: The calculated temperature distribution with distance between cell-phone and head tissues (brain, skin, bone and fat) exposed to $1800 \mathrm{MHz}$ frequency for 1 minute 


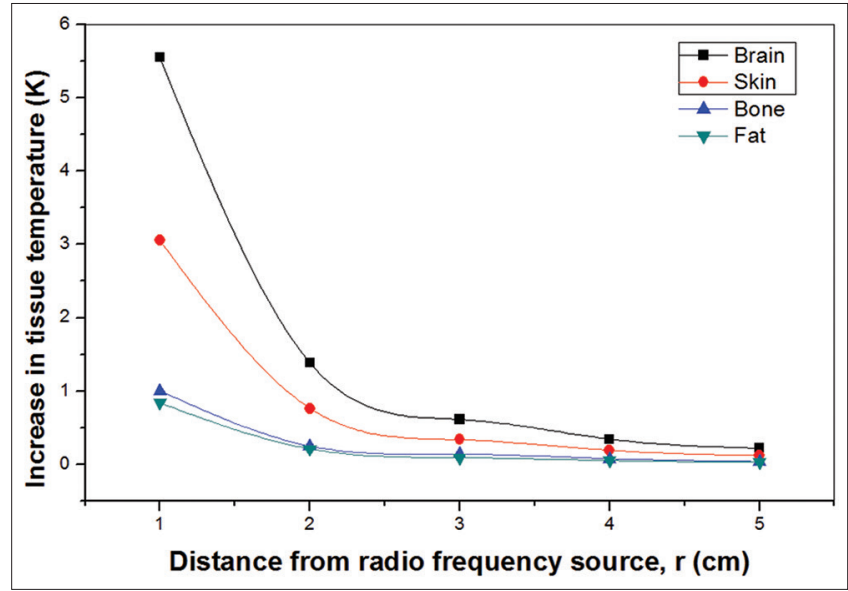

Fig. 9: The calculated temperature distribution with distance between cell-phone and head tissues (brain, skin, bone and fat) exposed to $1800 \mathrm{MHz}$ frequency for 5 minutes

temperature rise, it is observed that talk time of 5 minutes could be considered hazardous. The steady increase in tissue temperature beyond $4.5 \mathrm{~K}$ can affect protective mechanism for heat control and may have health consequences including cancer and memory loss $[14,15]$. In the work done by the Sallomi, the temperature rise was observed to be highest for skin tissue as compared to brain tissue [16]. However, the present studies found the brain tissue to be the most sensitive tissue as analyzed by temperature rise.

\section{CONCLUSION}

SAR distribution and temperature increase have been evaluated in a human head tissues exposed to the Global System for Mobile Communication frequencies 900 and $1800 \mathrm{MHz}$ from cellular phones. Temperature rise in brain tissue for talk time of 5 minutes from mobile phone is found to be $23 \%$ more than safe limit which is taken as $4.5 \mathrm{~K}$ for the present study. However, such hazardous effect can be minimized if one uses speaker or earphone for long duration call. The present studies have been carried out for frequencies 900 and $1800 \mathrm{MHz}$. With the advent of 3G and 4G mobile communication, the public is being exposed to higher radio frequency radiations. Hence, the future work should consider higher frequencies and the tissue damage caused by those frequencies.

\section{ACKNOWLEDGMENT}

The author is thankful to Lovely Professional University, for providing the necessary facilities to carry out this work.

\section{REFERENCES}

1. Scientific American; 2016. Available from: http://www scientificamerican.com/article/major-cell-phone-radiation-studyreignites-cancer-questions/.

2. Bio-Initiative Report, A Rationale for a Biologically-based Public Exposure Standard for Electromagnetic Radiation; 2012. Available from: http://www.bioinitiative.org. [Last accessed on 2012 Dec 31].

3. Abdelati M. Electromagnetic radiation from mobile base stations at Gaza. J Islam Univ Gaza (Nat Sci Ser) 1996;13(2):129-46.

4. Kumar V, Vats RP, Pathak PP. Harmful effects of 41 and $202 \mathrm{MHz}$ radiations on some body parts and tissues. Indian J Biochem Biophys 2008;45(4):269-74.

5. Kumar A, Kumar V, Pathak PP. Specific Absorption Rate (SAR) due to variation in frequency on human body tissues near radio broadcasting antenna. Asian J Pharm Clin Res 2015;8(1):120-4.

6. Godra C. Handbook of Antennas in Wireless Communications. $1^{\text {st }}$ ed. USA: CRC Press; 2002

7. Fujimoto K. Mobile Antenna Systems Handbook. $3^{\text {rd }}$ ed. Norwood, MA: Artech House, Inc.; 2008.

8. Guyton A, Hall JE. Medical Physiology. Ch.73. Philadelphia, PA: Saunders; 1996.

9. Adair ER, Adams BW, Akel GM. Minimal changes in hypothalamic temperature accompany microwave-induced alteration of thermoregulatory behavior. Bioelectromagnetics 1984;5(1):13-30.

10. Ghandi OP. Biological Effects and Medical Applications of Electromagnetic Energy. Englewood Cliffs, NJ: Prentice Hall; 1990.

11. Guy AW, Chow CK. Specific absorption rates of energy in man models exposed to cellular UHF-mobile antenna fields. IEEE Trans Microw Theory Tech 1996;34(6):671-80

12. Polk C. In: Polk C, Postow E, editors. Handbook of Biological Effects of Electromagnetic Fields. Boca Raton, USA: CRC Press; 1996. p. 1-23.

13. Basandrai D, Dhami AK. Study of penetration depth and SAR of skin tissue exposed to cell-phone radiation. J Chem Pharm Res 2016;8(3):917-20.

14. Rubin CT, Mcleod KJ, Lanyon LE. Prevention of osteoporosis by pulsed electromagnetic fields. J Bone Joint Surg Am 1989;71(3):411-8

15. Matanoski GM, Elliot EA, Breysse PN, Lynberg MC. Leukemia in telephone linemen. Am J Epidemiol 1993;137(6):609-19.

16. Sallomi A. Theoretical approach for SAR calculation in human head exposed to RF signals. J Eng Dev 2012;16(4):1813-7822. 